dextrane. Virus yield was reduced to about $2 \%$ of the controls (line 2,13-16). If RNA-synthesis is inhibited by the addition of Actinomycin D, the inhibition of virus growth by poly $(\mathrm{rI}) \cdot \operatorname{poly}(\mathrm{rC})$ is prevented and the virus yield is the same or even enhanced compared to control cultures (line 4, 17-20). These findings are similar to those obtained previously with Sindbis Virus and suggest that poly $(\mathrm{rI}) \cdot \operatorname{poly}(\mathrm{rC})$ exerts its effect by inducing the formation of one or more intermediate substances, which are responsible for the growth inhibition of Semliki Fores Virus ${ }^{3,4}$. One possibility which cannot be excluded though is that

1 C. Colby, The Induction of Interferon by Natural and Synthetic Polynucleotides, in: J. N. Davidson and W. E. CoHn, "Progress in Nucleic Acid Research", p. 1, Bd. 11, Academic Press, New York 1971.

2 T. W. Schafer and R. Z. Lockart, Nature [London] 226, 449 [1970].

3 J. TAylor, Biochem. biophysic. Res. Commun. 14, 447 [1964], and manuscript in preparation.

\section{Biosynthesis of Juvenile Hormone from 10-epoxy-7-ethyl-3,11-dimethyl-2,6-trideca- dienoic Acid in the Adult Cecropia Moth}

Manfred Metzler, Dietrich Meyer,
Karl Heinz Dahm, and Herbert Röller

Institute of Life Science, Department of Biology, Texas A\&M University, College Station, Texas 77843, U.S.A. and

John B. Siddall

Zoecon Corporation, Research Laboratory Palo Alto, California 94303, U.S.A.

(Z. Naturforsch. 27 b, 321-322 [1972] ; received August 9, 1971)

The biosynthesis of juvenile hormone $(\mathrm{JH}, \mathbf{1})$ and its lower homologue (JH-II, 2) in the adult silkmoth Hyalophora cecropia (L.) involves L-methionine, which provides the ester methyl group for both compounds ${ }^{1}$. The substrate for the methylation reaction, however, has not yet been identified. We now wish to report that adult male $H$. cecropia are able to synthesize JH from dl-trans,trans,cis-10-epoxy-7-ethyl-3,11-dimethyl-2-6-tridecadienoic acid (3). For the preparation of labelled 3 we took advantage of the fact that $\mathrm{JH}$, when injected into late fifth instar larvae of the tobacco hornworm, Manduca sexta (JOHANNSON), is rapidly inactivated

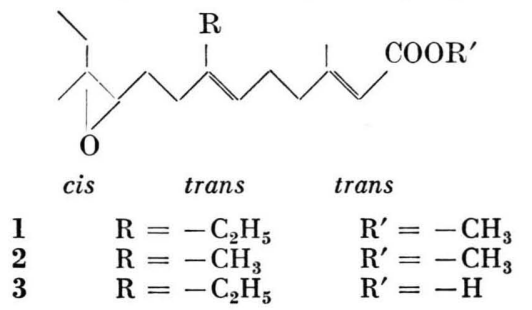

Requests for reprints should be sent to Dr. H. RöLleR, Institute of Life Science, Department of Biology, Texas A\&M University, College Station, Texas 77843, U.S.A. poly $(\mathrm{rI}) \cdot \operatorname{poly}(\mathrm{rC})$ inhibits virus growth not by inducing specifically an antiviral substance but rather because of an unspecific toxic effect on the host cell, which is not appearing in Actinomycin D treated cells. Since it has been shown that doublestranded poly. nucleotides can induce interferon this type of protein is one of the possible candidates for an induced intermediate substance. Besides the possibility of additional sofar not detected antiviral substances in poly(rI) poly $(\mathrm{rC})$ treated cells the presence of interferon could secondarily result in the induction of other cellular antiviral proteins.

4 M. Matsuyama, J. Kawade, and T. Fukada, Jap. J. Microbiol. 14, 303 [1970].

5 E. Kjeldsberg and M. Flikke, J. Gen. Virol. 10, 147 [1971].

6 A. K. Field, A. A. Tytell, G. P. Lampson, and M. R. Hilleman, Proc. natl. Acad. Sci. USA 58, 1004 [1967].

by enzymatic hydrolysis to $\mathbf{3}^{2}$. Labelled 3 was most conveniently prepared by in vitro incubation of $2{ }^{14} \mathrm{C}$ $d l$-JH with Manduca blood.

\section{Materials and Methods}

$2 \cdot{ }^{14} \mathrm{C}-d l-\mathrm{JH}^{3} \quad\left(5.0 \cdot 10^{6} \mathrm{dpm}, \quad\right.$ spec. act. $25 \mathrm{mCi} /$ mmole) was incubated at $37^{\circ}$ with $2 \mathrm{ml}$ hemolymph of 13-19 day-old last instar larvae of $M$. sexta. After $2 \mathrm{hrs}$. the mixture was extracted four times with $2 \mathrm{ml}$ ether-ethanol $(2: 1)$ and the extract resolved by thin layer chromatography on silica gel with hexane-ethyl acetate $(7: 3)$. The epoxy acid on the TLC-plate $\left(R_{f}\right.$ $\sim 0.3$ ) was located with a radio scanner and eluted with peroxide free tetrahydrofuran $\left(3 ; 4.1 \cdot 10^{6} \mathrm{dpm}\right.$, $82 \%)$. From a second zone $\left(R_{f} \sim 0.8\right)$ unchanged $\mathrm{JH}$ was recovered $\left(1 ; 0.87 \cdot 10^{6} \mathrm{dpm}, 17 \%\right)$.

The epoxy acid 3 was dissolved in TRIS/HCL buffer $\mathrm{pH} 8.5$ just prior to application and injected ( 3 male Cecropia moths, 2 days old, $50 \mu \mathrm{l} / \mathrm{moth}$ ) through the membrane between the 6 th and 7 th abdominal segments. In a second experiment [methyl- $\left.{ }^{3} \mathrm{H}\right]-\mathrm{L}-\mathrm{methionine}(2.6$ $\mathrm{Ci} / \mathrm{mmole}$, Schwarz Bioresearch Inc. N. Y., in InsectRinger solution, $30 \mu \mathrm{l} /$ moth) was administered together with 3 . The other experimental conditions and the isolation procedure for $\mathrm{JH}$ and $\mathrm{JH}$-II were the same as previously described ${ }^{1,4}$.

\section{Results and Discussion}

Five hours after injection of the racemic $2{ }^{14} \mathrm{C}$-epoxy acid 3 into 2 day-old male Cecropia moths the $\mathrm{JH}$ was isolated. It contained $3.9 \%$ of the administered label (Table I, experiment 1 ). In a second experiment [methyl ${ }^{3} \mathrm{H}$ ]-L-methionine was injected simultaneously with $2{ }^{14} \mathrm{C}-3$ and the incubation period extended to 15 hours (Table I, experiment 2 ). In this case $5.8 \%$ of the ${ }^{14} \mathrm{C}$ and $0.11 \%$ of the ${ }^{3} \mathrm{H}$ was recovered with the $\mathrm{JH}$. The purity of the isolated $\mathrm{JH}$ was checked through catalytic hydrogenation: the reaction product methyl 3,11-dimethyl-7-ethyl-tridecanoate ${ }^{5}$ after gas chromatographic 
purification ${ }^{1}$ had the same $\mathrm{dpm}{ }^{3} \mathrm{H} / \mathrm{dpm}{ }^{14} \mathrm{C}$ ratio $(2.39: 1)$ as the starting material $(2.43: 1)$. In the second experiment also JH-II was isolated; it contained ${ }^{3} \mathrm{H}$ but no detectable ${ }^{14} \mathrm{C}$ activity. Exogenous

\begin{tabular}{|c|c|c|}
\hline & $\begin{array}{l}\text { Experi- } \\
\text { ment } 1\end{array}$ & $\begin{array}{l}\text { Experi- } \\
\text { ment } 2\end{array}$ \\
\hline $\begin{array}{l}\text { 2-14C-epoxy acid } 3 \\
\text { dose/moth [dpm] } \\
\text { [methyl-3H]-L-methionine, }\end{array}$ & $430 \times 10^{3}$ & \\
\hline $\begin{array}{l}\text { dose/moth [dpm] } \\
\text { incubation period [hrs.] }\end{array}$ & -5 & $\begin{array}{l}55 \times 10^{6} \\
15\end{array}$ \\
\hline $\begin{array}{r}\mathrm{JH} \text { isolated per moth }[\mu \mathrm{g}] \\
{\left[\begin{array}{l}{\left[\mathrm{dpm}{ }^{14} \mathrm{C}\right]} \\
{\left[\mathrm{dpm}{ }^{3} \mathrm{H}\right]}\end{array}\right.}\end{array}$ & $\begin{array}{l}1.4 \\
16.7 \times 10^{3} \\
-\end{array}$ & $\begin{array}{l}1.8 \\
20.2 \times 10^{3} \\
62.2 \times 10^{3}\end{array}$ \\
\hline $\begin{array}{r}\text { JH-II isolated per moth }[\mu \mathrm{g}] \\
{\left[\mathrm{dpm}^{14} \mathrm{C}\right]} \\
{\left[\mathrm{dpm}^{3} \mathrm{H}\right]}\end{array}$ & $\begin{array}{l}- \\
- \\
-\end{array}$ & $\begin{array}{l}0.4 \\
0 \\
11.3 \times 10^{3}\end{array}$ \\
\hline
\end{tabular}

Table I. Incorporation-experiments with $2{ }^{14} \mathrm{C}$-dl-trans,trans, cis-10-epoxy-7-ethyl-3,11-dimethyl-2,6-tridecadienoic acid and [methyl- ${ }^{3} \mathrm{H}-$ - $-\mathrm{L}-\mathrm{methionine.} \mathrm{Three} 2$ day-old male Cecropia moths were used in each experiment.

1 M. Metzler, K. H. Dahm, D. Meyer, and H. Röller, Z. Naturforsch., in press.

2 M. Slade, C. H. Zibitt, J. B. Siddall, Proc. IUPAC Symposium, Tel Aviv [1971], in press.

3 W. Hafferl, R. ZurflüH, and L. Dunham, J. Label. Cpds. $7,331[1971]$.
JH administered to adult $H$. cecropia is rapidly metabolized, and after 24 hours only $10 \%$ of the hormone could be recovered unchanged (unpublished results). In view of the high rate of incorporation of the acid 3 into $\mathrm{JH}-\sim 10 \%$ after 15 hours, assuming a $\mathrm{JH}$ recovery of $\sim 50 \%$ - it appears unlikely that the inactivation of $\mathrm{JH}$ in this animal proceeds primarily through hydrolysis to the acid 3 . On the other hand, 3 is not necessarily a natural precursor in the biosynthesis of JH. Conceivably another acidic compound is methylated and afterwards, perhaps by epoxidation, converted to the JH. Experiments with JH have shown that its biological activity depends largely on the carrier with which it is administered ${ }^{6}$. These results may be explained by the differing degrees of protection afforded by the carriers in the presence of degrading enzyme systems. It is also possible that exogenous $\mathrm{JH}$ is not degraded through the same metabolic pathways as endogenous $\mathrm{JH}$.

The authors wish to express their appreciation to $\mathrm{Mr}$. Charles H. Zibitt, Zoecon Corporation, Research Laboratory, for his expert technical contributions.

Part of the work was supported through grants from the National Science Foundation (GB-7941) and the Cotton Producers Institute (CPI 69-139).

${ }^{4}$ K. H. DAHM and H. Röller, Life Sci. Pt. 2, 9, 1397 [1970].

5 H. Röller, K. H. Dahm, C. C. Sweeley, and B. M. Trost, Angew. Chem. 79, 190 [1967] ; Angew. Chem. Int. Ed. 6. 179 [1967].

6 H. Röller and K. H. Dahm, Recent Prog. Hormone Res. 24, 671 [1968].

\section{Fish Eggs: Another New Source of Polyvalent Proteinase-Isoinhibitors}

\section{G. Uhlenbruck *, I. Sprenger *, G. Hermann **, and H. FrANKE **}

From the Immunological Departments of the Medical University Clinic (Head: Prof. Dr. R. Gross) and the University Clinic of Surgery (Head: Prof. Dr. G. Heberer), Cologne

(Z. Naturforsch. 27 b, 322-323 [1972] ; received December 13, 1971)

It has recently been demonstrated ${ }^{1}$ that the albumin gland of snails not only supports the snail eggs with anti-bacterial and blood or tumor cell crossreacting agglutinins (protectins) ${ }^{2}$, but also with large amounts of polyvalent proteinase-isoinhibitors, several of which could be detected by the method of fibrin-agar-electrophoresis in a great number of different and quite unrelated snail eggs ${ }^{3,4}$.

Requests for reprints should be sent to Prof. Dr. G. UHLEN BRUCK, Abteilung für Immunbiologie, D-5000 Köln 41, Kerpener Str. 15.

* Prof. Dr. G. Uhleneruck and Dr. I. Sprenger, Abteilung für Immunbiologie, D-5000 Köln 41, Kerpener Straße 15.
Subsequently we tested some fish eggs for the presence of proteinase-inhibitors, as the occurrence of heterophile agglutinins in certain fish eggs had already been described following the discovery of agglutinins in snail eggs ${ }^{2}$. The importance of these egg proteinaseinhibitors and agglutinins is not very well understood. It may be that they have a protective function towards bacterial invasion or that they are used in order to neutralize the sperm penetrating protease acrosin ${ }^{5,6}$. The fact that proteinase-inhibitors are also known to occur in chicken, turkey and other avian eggs (avian egg white inhibitors) ${ }^{7}$ points out that we are dealing here with a wide spread biological phenomenon, which offers itself for clinical investigations and awaits further practical applications ${ }^{8}$.

Fibrin-agar-electrophoresis was performed as described in detail previously ${ }^{3,4}$, where also the source of the proteolytic enzymes is given. Fresh or frozen

* Prof. Dr. Dr. G. Hermann und H. Franke, Immunologische Abteilung der Chirurgischen Universitätsklinik, D-5000 Köln 41, Robert-Koch-Straße 10. 